\title{
Organic soils promote the efficacy of entomopathogenic nematodes, with different foraging strategies, in the control of a major forest pest: A meta-analysis of field trial data
}

\author{
Christopher D. Williams $^{\mathrm{a}, *}$, Aoife B. Dillon ${ }^{\mathrm{b}}$, Robbie D. Girling ${ }^{\mathrm{a}, 1}$, Christine T. Griffin ${ }^{\mathrm{a}}$ \\ ${ }^{a}$ Behavioural Ecology and Biocontrol Laboratory, Department of Biology, National University of Ireland Maynooth, Co. Kildare, Ireland \\ ${ }^{\mathrm{b}}$ Coillte Teoranta, Newtownmountkennedy, Co. Wicklow, Ireland
}

\section{H I G H L I G H T S}

- A meta-analysis of field trials for the control of pine weevil by EPN was conducted.

- EPN are more effective controls of pine weevil on peat than mineral substrates.

- Efficacy was independent of host density and tree species.

- Results are robust for both a 'cruiser' and an 'ambush' foraging EPN.

- The 'cruiser' is more efficacious than the 'ambush' forager.

\section{A R T I C L E I N F O}

\section{Article history:}

Received 28 August 2012

Accepted 23 March 2013

Available online 1 April 2013

\section{Keywords:}

Forest pest management

Pine weevil

Entomopathogenic nematodes

Inundative biological control

\section{G R A P H I C A L A B S T R A C T}

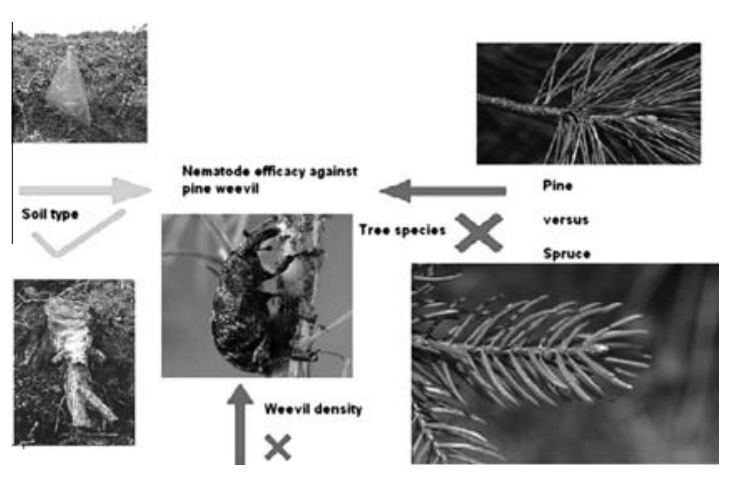

\begin{abstract}
A B S T R A C T
The large pine weevil, Hylobius abietis, is a serious pest of reforestation in northern Europe. However, weevils developing in stumps of felled trees can be killed by entomopathogenic nematodes applied to soil around the stumps and this method of control has been used at an operational level in the UK and Ireland. We investigated the factors affecting the efficacy of entomopathogenic nematodes in the control of the large pine weevil spanning 10 years of field experiments, by means of a meta-analysis of published studies and previously unpublished data. We investigated two species with different foraging strategies, the 'ambusher' Steinernema carpocapsae, the species most often used at an operational level, and the 'cruiser' Heterorhabditis downesi. Efficacy was measured both by percentage reduction in numbers of adults emerging relative to untreated controls and by percentage parasitism of developing weevils in the stump. Both measures were significantly higher with $H$. downesi compared to S. carpocapsae. General linear models were constructed for each nematode species separately, using substrate type (peat versus mineral soil) and tree species (pine versus spruce) as fixed factors, weevil abundance (from the mean of untreated stumps) as a covariate and percentage reduction or percentage parasitism as the response variable. For both nematode species, the most significant and parsimonious models showed that substrate type was consistently, but not always, the most significant variable, whether replicates were at a site or stump level, and that peaty soils significantly promote the efficacy of both species. Efficacy, in terms of percentage parasitism, was not density dependent.
\end{abstract}

(C) 2013 Elsevier Inc. All rights reserved.

\footnotetext{
* Corresponding author.

E-mail address: chris.david.williams@gmail.com (C.D. Williams).

${ }^{1}$ Current address: Centre for Biological Sciences, University of Southampton, Southampton, UK.
}

\section{Introduction}

The large pine weevil, Hylobius abietis (L.), is the most serious pest of reforestation in Europe costing the forestry sector millions 
of euro per annum e.g. $€ 2.57$ million ( $\$ 3.36$ million) a year in the UK and up to $€ 30$ million (\$38.84 million) annually in Sweden (Weslien, 1998; Leather et al., 1999; Långström and Day, 2004). If no chemical control measures were used against the pine weevil, the most recent estimate for the economic damage that would result across Europe was $€ 140$ million ( $\$ 181.26$ million) (Långström and Day, 2004). Adult weevils are attracted to volatile chemical cues which are emitted when coniferous trees are felled. Females oviposit in the stump, with larvae and pupae developing in or under the bark (Leather et al., 1999) often at depths in excess of $20 \mathrm{~cm}$. On emergence, adults feed on the bark of young trees planted on the clearfelled site, which can result in death through 'ring barking'. Without control measures, weevils can destroy up to $100 \%$ of newly planted trees, with a UK national average estimate of 50\% mortality within the first few years at untreated sites (Heritage and Moore, 2001).

The most popular current control measure involves treating young plants prior to planting with alpha cypermethrin or cypermethrin, with an additional top-up spray the year after planting (Coillte, 2012; Willoughby et al., 2004). However, with concerns over environmental impacts, cypermethrin is being phased out across Europe (E.C., 2012). Forest certification schemes require that alternatives to chemical control be sought wherever possible, and one of these bodies, the Forest Stewardship Council (FSC), specifically classifies cypermethrin and alpha-cypermethrin as "highly hazardous' chemicals, requiring that certificate holders possess a derogation to continue using these chemicals (FSC, 2011). These chemicals have been noted to have a repellence effect on the pine weevil and whereas this protects young plants, it does little to impact on the local populations of the pest (Torr et al., 2005; Leather et al., 1999). Current management practices, in addition to chemical control, include silviculture methods such as mounding, planting later in the season and leaving sites fallow (Von Sydow, 1997; Örlander and Nilsson, 1999; Örlander and Nordlander, 2003). Landscape level mitigation includes managing felling dates using decision support systems integrated with GIS to minimize weevil impacts (Wainhouse et al., 2001; Evans et al., 2004).

Entomopathogenic nematodes (EPN) have been used as an alternative method of controlling pine weevils (Dillon et al., 2007). Nematodes are applied as inundative biological control agents (biopesticides) targeted against pine weevil larvae, pupae and callow adults developing within the stumps. EPN are described as exhibiting different foraging strategies ranging from highly motile 'cruisers', which actively seek out insect hosts, to extreme 'ambushers', which tend to remain near the soil surface until hosts approach (Lewis et al., 1992, 2006; Grewal et al., 1994). We have previously shown that Heterorhabditis downesi (Stock, Griffin, and Burnell), a 'cruiser' forager, was best at controlling the subterranean cryptic pest, but Steinernema carpocapsae (Weiser), an 'ambusher', was also effective (Dillon et al., 2006). At operational level, $S$. carpocapsae is applied by pressure hose, from a tank mixer mounted on a modified forwarder, at an average rate of 3.5 million nematodes per stump (Torr et al., 2005). These operations are conducted by growers in the UK and Ireland, mainly the Forestry Commission and Coillte, respectively. For experiments, however, nematodes are usually applied by hand as a sub-surface drench. Entomopathogenic nematodes are harmless to humans, other warm blooded animals and plants (Boemare et al., 1996). They are also generally environmentally safe (Ehlers and Hokkanen, 1996) and have been shown to have little impact on non-target Coleoptera abundance, species richness, diversity or community composition when applied in clear-felled plantation forest ecosystems (Dillon et al., 2012).

The aim of the present study was to provide a meta-analysis of field trials which have tested the efficacy of entomopathogenic nematodes in the control of the large pine weevil. We focus on the only two species of nematode that have been commonly and repeatedly applied in such field trials: $S$. carpocapsae and H. downe$s i$. The advantages of focusing on these species is that $S$. carpocapsae is the species widely used at an operational level, but $H$. downesi has shown the best results to date (Dillon et al., 2006, 2007) and the two species represent two different foraging strategies, namely that of an 'ambusher' and that of a 'cruiser', respectively. Specifically we sought to investigate the importance of tree species and soil type on nematode efficacy, and whether the levels of control achieved were related to the size of the host population (density dependent).

\section{Materials and methods}

We collated data from published field studies which used EPN as biopesticides to control the large pine weevil in Britain and Ireland (Table 1) and also included our own unpublished data. We contacted workers of published studies to request unpublished data and have also included unpublished data from Evans et al. (Table 1). In total 28 trials were analysed in this meta-analysis (Table 1). Exact locations of study sites and methods can be found in the relevant papers cited in Table 1. Locations (latitude and longitude), altitude and year of application of our twelve previously unpublished trials are presented in Appendix A. The following description of methods relates only to our previously unpublished data, but similar methods were used in the published studies of Table 1.

\subsection{Nematode application}

In July 2007, S. carpocapsae was applied to approximately 150 ha (5 sites) of forests in the estate of Coillte, the Irish stateowned forestry company. All of these trials involved a single tree species except Lackenrea, which included both Lodgepole pine ( $P i$ nus contorta Douglas) and Sitka spruce (Picea sitchensis [Bong.] Carr.) stumps. Each tree species was treated as a separate trial in this case. In each trial, the majority of the stumps were treated with $S$. carpocapsae by pressure hose from a tank mixer mounted on a modified forwarder at an average rate of 3.5 million nematodes per stump, which is the standard operational protocol. A small number of stumps received $H$. downesi (5 trials) or were left untreated (all trials). H. downesi was applied by hand as a subsurface drench at the same rate as $S$. carpocapsae, using the same methods as Dillon et al. (2006). Also in July 2007 both nematode species were applied by hand at a sixth site (Knockeen). In June 2008 S. carpocapsae was applied by pressure hose to three further sites with untreated stumps left as controls. In June of 2010 and 2011, stumps at two additional sites (Summerhill and Kilduff) were treated with $S$. carpocapsae by hand using a sub-surface drench giving a total of twelve trials on eleven sites (Appendix A). Steinernema carpocapsae was supplied by Becker Underwood whereas $H$. downesi strain $\mathrm{K} 122$ was mass reared in wax moths according to the methods of Dillon et al. (2006).

\subsection{Assessment methods and experimental design}

Stumps were either destructively sampled 3-4 weeks after nematode application or covered with insect traps designed to catch emerging adults using a modified design based on Owen (1989). Untreated (control) and nematode-treated stumps were arranged in a randomized block design with one stump of each treatment per block. There were 10-20 blocks for each assessment method at each site (Appendix A). 
Table 1

Trials/sites, locations and summary data for the data-sets used in the present meta-analysis. Ire $=$ Ireland, Sco. $=$ Scotland, Subs. $=$ substrate, Cont. $=$ control of either no treatment or $500 \mathrm{ml}$ water, S.c = Steinernema carpocapsae, $\mathrm{H} . \mathrm{d}=$ Heterorhabditis downesi, \% red = percentage reduction relative to control, \% para = percentage parasitism. Superscripts denote published studies; those without superscripts are presented here for the first time.

\begin{tabular}{|c|c|c|c|c|c|c|c|c|c|c|}
\hline \multirow[t]{2}{*}{ Trial/site name } & \multirow[t]{2}{*}{ Location } & \multirow{2}{*}{$\begin{array}{l}\text { Year of } \\
\text { app. }\end{array}$} & \multirow{2}{*}{$\begin{array}{l}\text { Tree } \\
\text { species }\end{array}$} & \multirow[t]{2}{*}{ Subs. } & \multirow{2}{*}{$\begin{array}{l}\text { Destructive sampling } \\
\text { mean Cont. }\end{array}$} & \multirow{2}{*}{$\begin{array}{l}\text { Emergence trapping } \\
\text { mean Cont. }\end{array}$} & \multicolumn{4}{|c|}{ Measures of efficacy } \\
\hline & & & & & & & $\begin{array}{l}\text { \% red } \\
\text { S.c }\end{array}$ & $\begin{array}{l}\text { \% red } \\
\text { H.d }\end{array}$ & $\begin{array}{l}\% \text { para } \\
\text { S.c }\end{array}$ & $\begin{array}{l}\% \text { para } \\
\text { H.d }\end{array}$ \\
\hline Ballyroan trial $1^{\mathrm{a}}$ & Co. Laois, Ire. & 2001 & Pine & Peat & 93.3 & 140.7 & 48.5 & 87.0 & 25.0 & 66.2 \\
\hline Ballyroan trial $2^{\mathrm{a}}$ & Co. Laois, Ire. & 2002 & Pine & Peat & 126.0 & 84.4 & 11.0 & 87.2 & 15.5 & 60.5 \\
\hline Ballybrittas $^{\mathrm{a}}$ & Co. Laois, Ire. & 2003 & Pine & Peat & 67.2 & 37.1 & 60.0 & 67.7 & 47.0 & 55.2 \\
\hline $\mathrm{Emo}^{\mathrm{b}}$ & Co. Laois, Ire. & 2004 & Pine & Peat & 84.6 & 78.9 & 64.3 & 84.8 & 37.0 & 52.6 \\
\hline Donadea $^{\mathrm{b}}$ & Co. Kildare, Ire. & 2005 & Pine & Peat & 144.4 & 87.9 & 57.3 & 78.7 & 26.0 & 77.1 \\
\hline Glendine & Co. Laois, Ire. & 2007 & Pine & Peat & 84.3 & 53.2 & 70.7 & 80.6 & 14.0 & 37.0 \\
\hline Summerhill & Co. Meath, Ire. & 2010 & Pine & Peat & 80.8 & 260.5 & 53.9 & $\mathrm{n} / \mathrm{a}$ & 71.7 & $\mathrm{n} / \mathrm{a}$ \\
\hline Killduff & $\begin{array}{l}\text { Co. } \\
\text { Westmeath, } \\
\text { Ire. }\end{array}$ & 2011 & Pine & Peat & 30.4 & $\mathrm{n} / \mathrm{a}$ & $\mathrm{n} / \mathrm{a}$ & $\mathrm{n} / \mathrm{a}$ & 20.2 & $\mathrm{n} / \mathrm{a}$ \\
\hline Lairg $^{c}$ & N. Sco. & 2003 & Pine & Peat & $\mathrm{n} / \mathrm{a}$ & 33.0 & 70.9 & $\mathrm{n} / \mathrm{a}$ & 75.0 & $\mathrm{n} / \mathrm{a}$ \\
\hline Lairg $^{\mathrm{c}}$ & N. Sco. & 2003 & Pine & Peat & $\mathrm{n} / \mathrm{a}$ & 41.5 & 65.3 & $\mathrm{n} / \mathrm{a}$ & $\mathrm{n} / \mathrm{a}$ & $\mathrm{n} / \mathrm{a}$ \\
\hline Ballymacshaneboy & Co. Cork, Ire. & 2007 & Pine & Min & 34.9 & 55.1 & 13.7 & 75.1 & 9.0 & 34.1 \\
\hline Lackenrea trial 1 & $\begin{array}{l}\text { Co. Waterford, } \\
\text { Ire. }\end{array}$ & 2007 & Pine & Min & 56.0 & 29.0 & 29.0 & 63.4 & 3.0 & 18.5 \\
\hline Lackenrea trial 2 & $\begin{array}{l}\text { Co. Waterford, } \\
\text { Ire. }\end{array}$ & 2007 & Spruce & Min & 11.1 & 16.2 & 42.0 & 79.2 & 2.0 & 36.8 \\
\hline Annalecka $^{\mathrm{d}}$ & $\begin{array}{l}\text { Co. Wicklow, } \\
\text { Ire. }\end{array}$ & 2006 & Spruce & Min & 17.8 & $\mathrm{n} / \mathrm{a}$ & $\mathrm{n} / \mathrm{a}$ & $\mathrm{n} / \mathrm{a}$ & 10.0 & 43.5 \\
\hline Glendalough $^{\mathrm{d}}$ & $\begin{array}{l}\text { Co. Wicklow, } \\
\text { Ire. }\end{array}$ & 2006 & Spruce & Min & $\mathrm{n} / \mathrm{a}$ & 4.9 & 14.8 & 39.1 & $\mathrm{n} / \mathrm{a}$ & $\mathrm{n} / \mathrm{a}$ \\
\hline Ballinagee $^{\mathrm{d}}$ & $\begin{array}{l}\text { Co. Wicklow, } \\
\text { Ire. }\end{array}$ & 2004 & Spruce & Min & 18.8 & 1.5 & 25.0 & 33.3 & 9.0 & 17.8 \\
\hline Oakwood $^{\mathrm{d}}$ & $\begin{array}{l}\text { Co. Wicklow, } \\
\text { Ire. }\end{array}$ & 2005 & Spruce & Min & 5.3 & 18.3 & 10.4 & 49.0 & 12.0 & 31.1 \\
\hline Deerpark & $\begin{array}{l}\text { Co. Wicklow, } \\
\text { Ire. }\end{array}$ & 2007 & Spruce & Min & 8.6 & 13.4 & 32.2 & 74.2 & 21.0 & 45.5 \\
\hline The Rodneys & $\begin{array}{l}\text { Co. Limerick, } \\
\text { Ire. }\end{array}$ & 2007 & Spruce & Min & $\mathrm{n} / \mathrm{a}$ & 1.8 & 31.3 & $\mathrm{n} / \mathrm{a}$ & $\mathrm{n} / \mathrm{a}$ & $\mathrm{n} / \mathrm{a}$ \\
\hline Mount Leinster & Co. Carlow & 2008 & Spruce & Min & $\mathrm{n} / \mathrm{a}$ & 5.85 & 89.7 & $\mathrm{n} / \mathrm{a}$ & $\mathrm{n} / \mathrm{a}$ & $\mathrm{n} / \mathrm{a}$ \\
\hline Drumcor & Co. Cavan & 2008 & Spruce & Min & $\mathrm{n} / \mathrm{a}$ & 1.9 & 63.2 & $\mathrm{n} / \mathrm{a}$ & $\mathrm{n} / \mathrm{a}$ & $\mathrm{n} / \mathrm{a}$ \\
\hline Knockeen & $\begin{array}{l}\text { Co. Waterford, } \\
\text { Ire. }\end{array}$ & 2007 & Spruce & Peat & $\mathrm{n} / \mathrm{a}$ & 0.5 & 42.9 & 85.7 & $\mathrm{n} / \mathrm{a}$ & $\mathrm{n} / \mathrm{a}$ \\
\hline Glennakeel & Co. Cork & 2008 & Spruce & Peat & $\mathrm{n} / \mathrm{a}$ & 0.75 & 0 & $\mathrm{n} / \mathrm{a}$ & $\mathrm{n} / \mathrm{a}$ & $\mathrm{n} / \mathrm{a}$ \\
\hline Ae Forest trial $1^{\mathrm{e}}$ & $\begin{array}{l}\text { Dumfriesshire, } \\
\text { Sco. }\end{array}$ & 1997 & Spruce & Peat & $\mathrm{n} / \mathrm{a}$ & $\mathrm{n} / \mathrm{a}$ & $\mathrm{n} / \mathrm{a}$ & $\mathrm{n} / \mathrm{a}$ & 18.3 & $\mathrm{n} / \mathrm{a}$ \\
\hline Ae Forest trial $2^{\mathrm{e}}$ & $\begin{array}{l}\text { Dumfriesshire, } \\
\text { Sco. }\end{array}$ & 1997 & Spruce & Peat & $\mathrm{n} / \mathrm{a}$ & $\mathrm{n} / \mathrm{a}$ & $\mathrm{n} / \mathrm{a}$ & $\mathrm{n} / \mathrm{a}$ & 5.2 & $\mathrm{n} / \mathrm{a}$ \\
\hline Cwm Berwyn ${ }^{f}$ & W. Wales & 2010 & Spruce & Min & 2.24 & 0.84 & 22.1 & $\mathrm{n} / \mathrm{a}$ & 17.9 & $\mathrm{n} / \mathrm{a}$ \\
\hline Cwm Berwyn ${ }^{\mathrm{f}}$ & W. Wales & 2011 & Spruce & Min & 1.74 & 3.08 & 63.6 & $\mathrm{n} / \mathrm{a}$ & 69.0 & $\mathrm{n} / \mathrm{a}$ \\
\hline Cwm Berwyn ${ }^{\mathrm{f}}$ & W. Wales & 2012 & Spruce & Min & 8.24 & 8.88 & 94.5 & $\mathrm{n} / \mathrm{a}$ & 38.8 & $\mathrm{n} / \mathrm{a}$ \\
\hline
\end{tabular}

a From Dillon et al. (2006).

b From Dillon et al. (2007).

c From Torr et al. (2007).

d From Dillon et al. (2008)

e From Brixey et al. (2006).

f Personal communication Prof. H. Evans et al.; unpublished results from joint work by Forest Research and Swansea University under the EU Interreg IVA IMPACT project.

\subsubsection{Destructive sampling to assess percentage parasitism}

Destructive sampling, by removing bark with a chisel and recording the number of weevils parasitized, followed the methods of Dillon et al. (2006) with the modification that entire Sitka spruce stumps were destructively sampled and only one quarter of the Lodgepole pine stumps were sampled in this way. To allow comparison between tree species, values for the Lodgepole pine stumps were multiplied by four throughout.

\subsubsection{Emergence trapping}

Insect emergence traps were erected within one week of nematode application, except on The Rodneys where traps were not erected until 4 weeks after application in order to facilitate replanting. Traps were emptied every 2 weeks until the end of October or early November, by which time no more weevils were emerging. At each assessment date, trapped adult $\mathrm{H}$. abietis were removed and counted.

\subsection{Statistical analysis}

General linear models (GLMs) were constructed for each entomopathogenic nematode species separately. Percentage parasitism or percentage reduction in emergence was coded as a response variable, where:

Percentage parasitism $=(\mathrm{NI} / \mathrm{TN}) \times 100$.

$\mathrm{NI}=$ number of individuals infected with nematodes; $\mathrm{TN}=$ total number of individuals collected and

Percentage reduction in emergence

$$
=([\text { E cont } .-\mathrm{E} \text { treat }] / \mathrm{E} \text { cont. }) \times 100 .
$$

$\mathrm{E}$ cont. $=$ mean number of weevils emerging per control stump; $\mathrm{E}$ treat $=$ mean number of weevils emerging per nematode-treated stump. 
In the GLMs, tree species (Sitka spruce versus Lodgepole pine) and substrate (peat versus mineral) were coded as fixed factors and mean number of pine weevils per stump was coded as a covariate. Sites with over $40 \mathrm{~cm}$ of deep peat were considered to be peaty sites whereas those with minimal peat cover or small pockets of peat over mineral soils were considered to be mineral soils. The peaty sites were $100 \%$ organic matter whereas mineral sites had variable proportions of sand, silt and clay. Ireland's semi-state forestry company, Coillte, record site substrates as either peaty or mineral on their database, by the same criteria. Where possible, first order interactions were included in the initial model. After considering the most complete model possible, variables were sequentially removed according to their $P$ values until a parsimonious model with good performance, assessed by changes in the model significance and the adjusted $r$ squared value, was attained.

Models were constructed for both 'site-level' and 'stump-level' data; the former with sites as replicates and the latter with stumps as replicates. Stump-level analyses could be considered pseudoreplicated data (Hurlbert, 1984), but we include these models as they highlight that variables that are important at a site-level are also important at a stump-level. For all stump-level data, the effect of 'site' is highly significant with respect to both numbers of weevils in stumps and percentage parasitism, for both the $S$. carpocapsae and the $H$. downesi data-sets $(P<0.001$ in all cases).

Standardized residuals of the General Linear Models constructed were not significantly different from normal distributions $(K-S$ test $P>0.05)$ in all cases ${ }^{2}$, except the stump-level data-set for $S$. carpocapsae-treated stumps ${ }^{3}$. For this reason these data were transformed using a $\log _{10}$ (value +1 ) transformation.

Pearson's and Spearman rank correlations were performed on percentage parasitism versus number of pine weevil in the stump for each site for which data were available, i.e. studies for which we had stump-level data, and on the data-set as a whole.

All statistical analyses were performed on SPSS version 19 (SPSS, 2011).

\section{Results}

\subsection{Numbers of Weevils emerging from untreated stumps}

The total number of pine weevils emerging per untreated (control) stump was significantly affected by tree species, but not substrate, with more weevils emerging from pine compared to spruce. A two way ANOVA with gave a significant effect of tree species $(P=0.022)$, but not substrate $(P=0.410)$ or the tree species $\times$ substrate interaction $(P=0.287)$ (Fig. 1$)$.

\subsection{Comparison of nematode species}

On sites where both nematode species were applied, $H$. downesi was a more successful control agent than $S$. carpocapsae, as measured by both methods of efficacy (paired $T$-test, paired by site, percentage reduction: $T=6.262$, d.f. $=13, P[2$ tailed $]<0.001$; percentage parasitism: $T=7.008$, d.f. $=12, P[2$ tailed $]<0.001$ ). The mean percentage reduction in emergence was $44.9 \%$ for $S$. carpocapsae-treated stumps compared with $70.4 \%$ for $H$. downesi-treated stumps. Percentage parasitism was $26.0 \%$ and $44.3 \%$ for S. carpocapsae-treated and $H$. downesi-treated stumps, respectively. The same trend is also seen for all sites, and also whether one considers peat or mineral sites separately (Table 1 ).

\footnotetext{
${ }^{2} \mathrm{~K}-\mathrm{S}$ test results: $\mathrm{S}$. carpocapsae, site-level, \% reduction data-set $P=0.985 \mathrm{~N}=24 ; \mathrm{S}$ carpocapsae, site-level, \% parasitism data-set $P=0.277 N=19 ;$ H. downesi site-level, \% reduction data-set $P=0.826 \mathrm{~N}=14 ; \mathrm{H}$. downesi site-level, \% parasitism data-set $P=0.963 N=13 ; H$. downesi stump-level, \% parasitism data-set $P=0.759 N=160$.

${ }^{3}$ S. carpocapsae stump-level, \% parasitism data-set $P=0.029 \mathrm{~N}=177$.
}

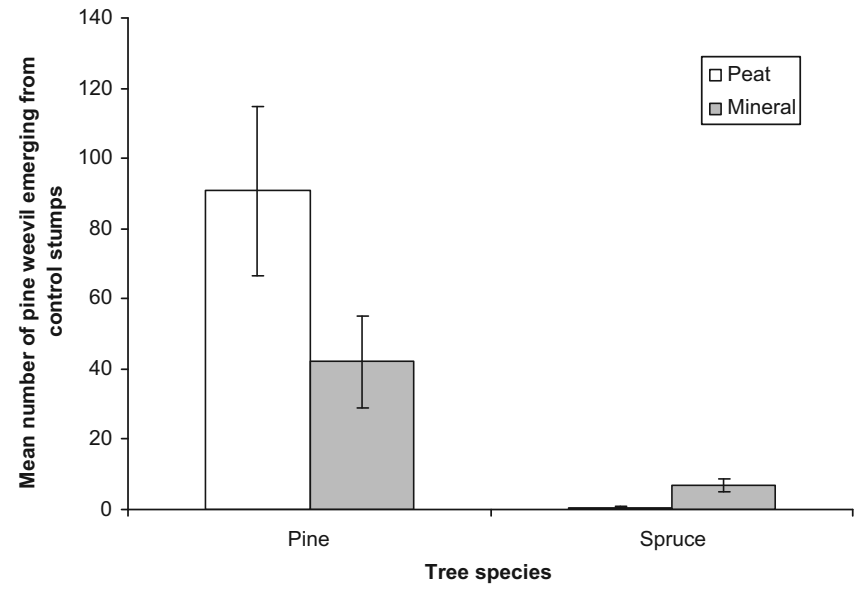

Fig. 1. Mean number of pine weevil (Hylobius abietis) emerging from untreated (control) stumps \pm standard error. Both factors are significant; $P=0.02$ for substrate and $P=0.004$ for tree species.

\subsection{Factors affecting the efficacy of entompathogenic nematode species}

In three of the six GLMs in Table 2 the most significant variable is substrate while in a fourth model, this variable approached significance. The lowest $P$ value for variables in the site-level percentage parasitism GLM for $S$. carpocapsae is also substrate. The only model in which another variable was significant is the site-level percentage parasitism GLM for $S$. carpocapsae, in which the tree species $\times$ substrate interaction was significant. However this model was itself not significant and had a low adjusted $R^{2}$ value compared to the other model. The other models explain much of the variation in the measures of efficacy, with adjusted $R^{2}$ values ranging from 0.562 to 0.961 , and four out of the six models explain over $75 \%$ of the variation in the measures of efficacy. Mean percentage reduction in emergence was $41.0 \%$ and $49.5 \%$ on mineral and peat soils, respectively, for S. carpocapsae-treated sites and 59.0\% (mineral) and $81.7 \%$ (peat) for $H$. downesi-treated sites (Fig. 2a). The mean percentage parasitism of weevils 3-4 weeks after application on S. carpocapsae-treated sites was $19.2 \%$ (mineral) and $32.3 \%$ (peat) and on $\mathrm{H}$. downesi-treated sites was $32.5 \%$ (mineral) and $58.1 \%$ (peat) (Fig. 2b).

The density of pine weevil per stump was not a significant predictor of nematode efficacy in any of the models at either a site-level or a stump-level. However, in order to further investigate if there were correlations between these variables at a stump-level within each site, both Pearson's and Spearman Rank correlations were performed on percentage parasitism versus the number of pine weevil individuals in each stump for each site separately. For the S. carpocapsae-treated stumps, of the 15 trials for which we had stump-level data, only two trials gave a significant correlation between these variables: Ballyroan trial 2 (Spearman rank correlation coefficient $=-0.644, P=0.044$ ) and Lackenrea trial 2 (Pearson's correlation coefficient $=0.565, P=0.015$; Spearman Rank correlation coefficient $0.612, P=0.007$ ). The most conservative Bonferroni correction would result in non-significant $P$ values for all correlations, although the Spearman Rank correlation of Lackenrea trial 2 was only marginally non-significant after the correction $(P=0.105)$. In the equivalent data-set for $H$. downesi-treated stumps, none of the 13 trials gave a significant correlation between percentage parasitism and host density. Given the low number of sites with significant correlations and the fact that in one case there was a positive correlation and a negative correlation in the other, host density does not appear to influence the efficacy of the two entomopathogenic nematodes in the present study. 
Table 2

General Linear Models of nematode efficacy against the large pine weevil (Hylobius abietis). Significant values are in bold type.

\begin{tabular}{|c|c|c|c|c|c|c|}
\hline Level of analysis & Response variable & Factor & $F$ ratio & $P$ & Adjusted $R^{2}$ & Model $P$ \\
\hline $\begin{array}{l}\text { Steinernema carpo } \\
\text { Site-level }\end{array}$ & Percentage parasitism & $\begin{array}{l}\text { Tree species } \\
\text { Substrate } \\
\text { No. pine weevils in stump }\end{array}$ & $\begin{array}{l}0.008 \\
1.419 \\
0.129\end{array}$ & $\begin{array}{l}0.931 \\
0.252 \\
0.724\end{array}$ & 0.562 & 0.002 \\
\hline Site-level & Percentage reduction & $\begin{array}{l}\text { Tree species } \\
\text { Substrate } \\
\text { Tree species } \times \text { substrate }\end{array}$ & $\begin{array}{l}0.282 \\
0.285 \\
3.603\end{array}$ & $\begin{array}{l}0.681 \\
0.679 \\
\mathbf{0 . 0 4 7}\end{array}$ & 0.093 & 0.183 \\
\hline Stump-level & $\log _{10}($ percentage parasitism +1$)$ & $\begin{array}{l}\text { Tree species } \\
\text { Substrate } \\
\text { No. pine weevil in stump }\end{array}$ & $\begin{array}{r}0.259 \\
27.719 \\
0.095\end{array}$ & $\begin{array}{r}0.612 \\
<\mathbf{0 . 0 0 1} \\
0.758\end{array}$ & 0.784 & $<0.001$ \\
\hline $\begin{array}{l}\text { Heterorhabditis do } \\
\text { Site-level }\end{array}$ & Percentage parasitism & $\begin{array}{l}\text { Tree species } \\
\text { Substrate }\end{array}$ & $\begin{array}{l}0.694 \\
9.874\end{array}$ & $\begin{array}{l}0.424 \\
\mathbf{0 . 0 1 0}\end{array}$ & 0.932 & $<0.001$ \\
\hline Site-level & Percentage reduction & $\begin{array}{l}\text { Tree species } \\
\text { Substrate } \\
\text { Tree species } \times \text { substrate }\end{array}$ & $\begin{array}{l}0.242 \\
4.720 \\
0.950\end{array}$ & $\begin{array}{l}0.633 \\
0.055 \\
0.353\end{array}$ & 0.961 & $<0.001$ \\
\hline Stump-level & Percentage parasitism & $\begin{array}{l}\text { Tree species } \\
\text { Substrate } \\
\text { No. pine weevils in stump }\end{array}$ & $\begin{array}{r}0.869 \\
22.782 \\
0.254\end{array}$ & $\begin{array}{r}0.353 \\
<\mathbf{0 . 0 0 1} \\
0.615\end{array}$ & 0.758 & $<0.001$ \\
\hline
\end{tabular}
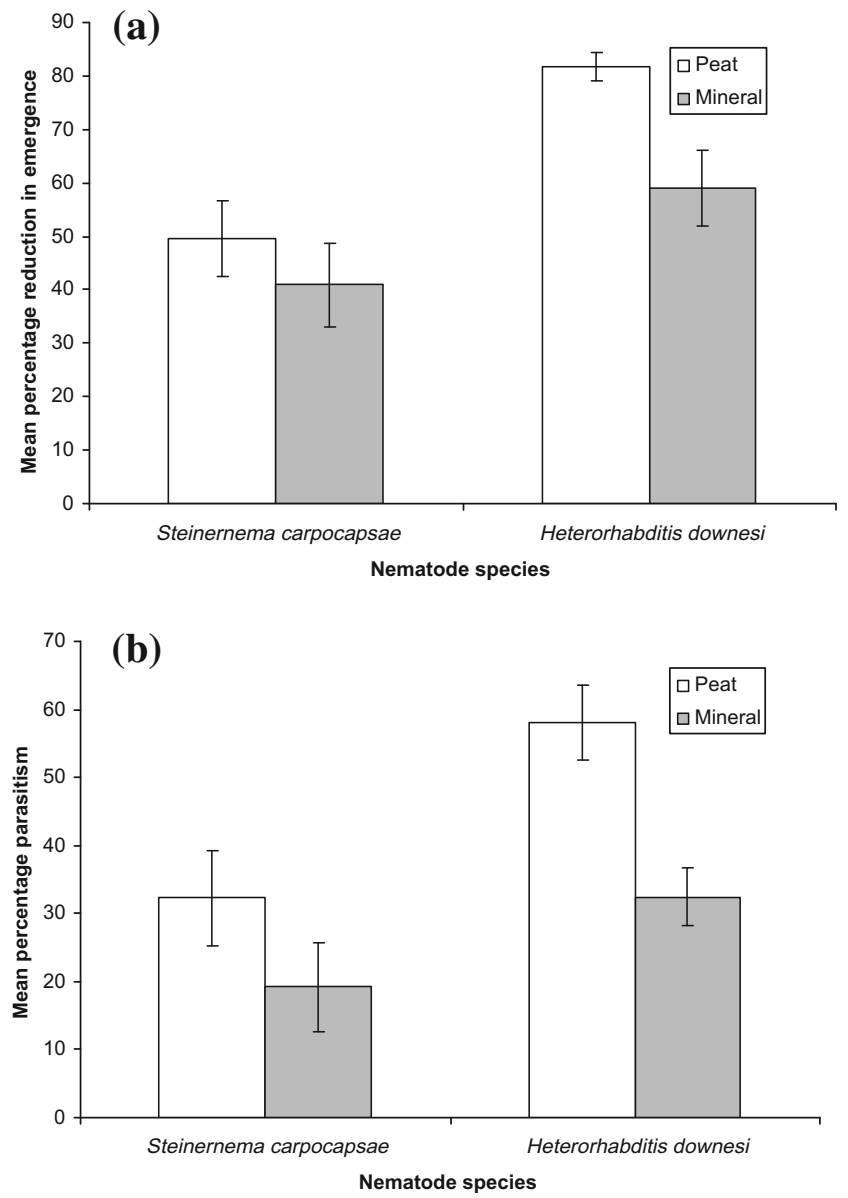

Fig. 2. Efficacy of Heterorhabditis downesi and Steinernema carpocapsae against Hylobius abietis as measured by both mean percentage reduction in emergence (a) and mean percentage parasitism (b) on peat and mineral sites. Error bars represent \pm one standard error.

When all of the stump-level data were pooled there were highly significant correlations between percentage parasitism and weevil density per stump in both $S$. carpocapsae-treated stumps
$\left(R^{2}=0.261 P<0.001, N=177\right)$ and $H$. downesi-treated stumps $\left(R^{2}=0.302, P<0.001, N=160\right)$. However, when the different substrates are considered separately, correlations are no longer significant ( $S$. carpocapsae on peat $R^{2}=-0.171, P=0.118, N=85 ; S$. carpocapsae on mineral $R^{2}=-0.052, P=0.624, N=92 ; H$. downesi on peat $R^{2}=-0.021, P=0.868, N=67 ; H$. downesi on mineral $\left.R^{2}=-0.166, P=0.112, N=93\right)$. These results, in Fig. 3, highlight the importance of considering substrate type to avoid spurious correlations between host density and percentage parasitism.

\section{Discussion}

Our analysis clearly shows that $H$. downesi is a more effective control agent of $\mathrm{H}$. abietis than is S. carpocapsae. Although in the present study all $H$. downesi were reared in vivo unlike $S$. carpocapsae, previous studies (Foster, Dillon and Griffin, unpublished) show that $H$. downesi can be as effective when reared on a trial basis by a commercial nematode-producing company. Our analysis shows that two species of EPN that typically exhibit different foraging strategies, $S$. carpocapsae and $H$. downesi, both show greater efficacy in clear-felled forests on organic soils than on mineral soils. It is likely that organic soils facilitate the active or passive movement of nematodes through the medium and into the stump or promote the post-application survival of nematodes.

There has been a small body of work comparing the efficacy of EPN in organic and mineral soils (Choo and Kaya, 1991; Koppenhöfer and Fuzy, 2006; Kruitbos et al., 2010), though there still remain significant gaps in knowledge on this subject. Oetting and Latimer (1991) found high infectivity of S. carpocapsae for Galleria mellonella (L.) in various organic potting media, but they did not compare between potting media and mineral soils. Choo and Kaya (1991) studied the effects of soil texture and roots on host finding by Heterorhabditis bacteriophora Poinar and observed higher infectivity in highly organic soils compared to sand, loam and clay soils. Koppenhöfer and Fuzy (2006) studied the effect of soil type on establishment and efficacy of four EPN species with variable results - a potting mix with high organic content was a poor medium for Steinernema scarabaei Stock and Koppenhöfer, but was the best medium for $H$. bacteriophora and Heterorhabditis zealandica Poinar, and was intermediate for Steinernema glaseri Steiner.

Organic soils tend to have a higher porosity and are less finely textured than mineral soils, but these variables have been shown 

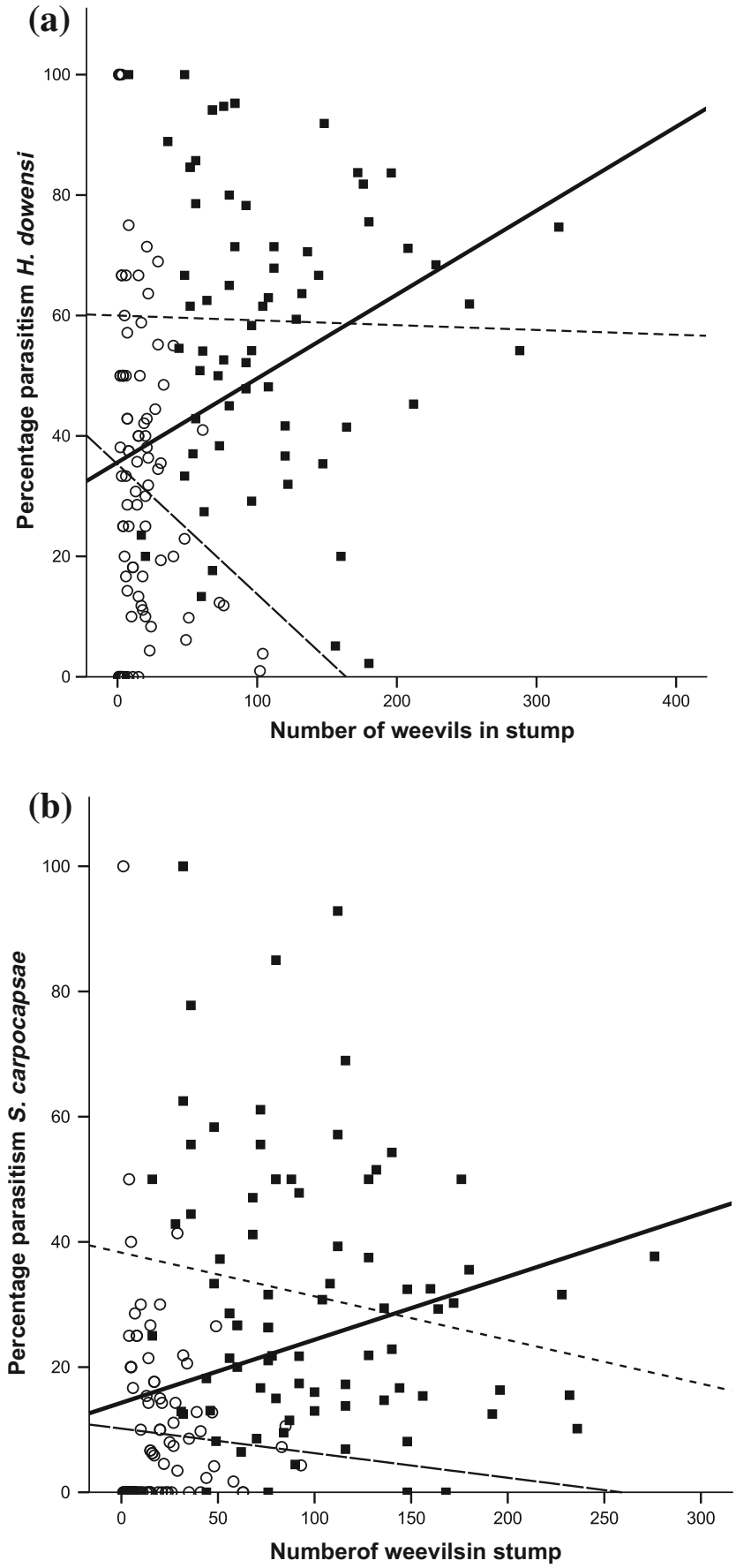

Fig. 3. At stump-level there is a significant linear regression between the number of weevils in the stump and the percentage parasitism for both (a) Heterorhabditis downesi $(P<0.001)$ and (b) Steinernema carpocapsae $(P<0.001)$ treated stumps solid lines. However, when different substrates are analysed separately there are no significant correlations $(P>0.05)$ - dotted lines are the correlation between stumps on peat substrates and broken lines those of stumps on mineral substrates.

to have different effects on nematodes in different study systems with finely textured soil promoting (Georgis and Gaugler, 1991; Shapiro et al., 2000; Koppenhöfer and Fuzy, 2006) or inhibiting (Georgis and Poinar, 1983; Molyneux and Bedding, 1984; Kung et al., 1990a; Koppenhöfer and Fuzy, 2006) the efficacy of both EPN genera. Bulk density has been shown to significantly affect EPN survival in experiments (Portillo-Aguilar et al., 1999) and competitive interactions in naturally co-occurring EPN species (Gruner et al., 2007). In peaty soils small un-degraded fibrous roots tend to persist to a greater depth in the rhizosphere than in mineral soils
(Foth, 1978; Pitty, 1979). Ennis et al. (2010) showed that roots can effectively act as routeways for the movement of $S$. carpocapsae IJs, so these small roots could contribute to the passage of EPN into the soil profile.

Soil moisture affects EPN survival, active movement and infectivity (Grant and Villani, 2003; Koppenhöfer et al., 1995; Kung and Gaulgler, 1991). Preisser and Strong (2004) have demonstrated the importance of soil moisture to the efficacy of natural EPN populations. Soil moisture is higher in clear-felled forests on peaty soils than on mineral equivalents (Paavilainen and Päivänen, 1995). As well as effects on active movement, IJs may also be passively carried downwards during application or by subsequent rainfall. For the passive movement of nematodes through the soil, effects of soil physical properties (porosity, texture etc.) and moisture regimes on IJs are likely to result in complex biophysical interactions, which are difficult to predict.

Another difference between mineral and peaty soils is $\mathrm{pH}$, with peaty soils being generally more acidic (Welsch et al., 1995), ranging from pH 4.2 to 4.7 (Butterfield, 1999). However, some granitederived mineral soils (e.g. schist-based soils) may be quite acidic and flushes and lags in some peatlands can be basic. There was no significant effect of $\mathrm{pH}$ in the range 4-8 on the pathogenicity of S. carpocapsae (Kung et al., 1990b) and so pH may not be a critical factor in the present study.

Kruitbos et al. (2010) showed that S. carpocapsae showed taxis towards a host in peat, but not in sand and also outcompeted Heterorhabditis megidis Poinar, Jackson and Klein in peat, but not in sand. Kruitbos et al. (2010) and Wilson et al. (2012) suggest that $S$. carpocapsae is a specialist of organic media rather than an 'ambusher' and used peat mescosms to test their hypothesis. However, it is worth noting that $H$. megidis always infected the deepest buried hosts in both sand and peat mesocosms, whereas $S$. carpocapsae infected none of the deepest-buried hosts (Kruitbos et al., 2010). Also, naturally occurring S. carpocapsae has been isolated from sandy soils (Alumai et al., 2006) though possibly in the thatch layer. Campbell et al. (1996) isolated 50\% of S. carpocapsae in the thatch layer and, by implication, $50 \%$ below that layer to a depth of $8 \mathrm{~cm}$. To our knowledge, $S$. carpocapsae has never been isolated from natural populations inhabiting peatland biotopes or other habitats in which an organism specialized at exploiting organic soil habitats might be expected to be found. Our analyses demonstrate that the 'cruiser' $H$. downesi is significantly more effective than $S$. carpocapsae on both peat and mineral soils, which is as would be predicted in the ambusher-cruiser paradigm where target organisms are 'cryptic' and rather 'sedentary', a description which is very apt for $H$. abietis larvae. If $S$. carpocapsae is a specialist of organic soils it might be expected to be more effective than $H$. downesi on clearfelled sites on organic soils, especially as both are effective against pine weevil developing stages in close-contact assays (Ennis, 2009; Dillon, unpublished data; Hennessy, unpublished data), although this was not the case.

Whereas our analysis shows that $S$. carpocapsae is more effective in controlling pine weevil in stumps on peaty rather than mineral soils, the same is true of $H$. downesi. The latter has only ever been recovered in very sandy coastal or alluvial soils (Rolston et al., 2005; Griffin et al., 1991, 1994, 1999). This suggests that nematodes are most effective in controlling pine weevil larvae in stumps on peaty soils regardless of the species' foraging strategy or the habitat from which they are usually isolated and in which they, presumably, evolved. This may be an example of a case in which the realized ecological niche of a species is quite a restricted sub-set of its fundamental niche and may indeed not be at its theoretical optimum (Hutchinson, 1957). However, a clear-felled conifer plantation and its usually high weevil populations are a highly artificial ecosystem and would certainly represent a novel ecological niche not available to either species in their evolution. 
The effects of host density on parasitism are well studied in insect host-parasitoid systems (Stilling, 1987) where approximately $50 \%$ of cases show density-dependence, with approximately $25 \%$ being positive and 25\% negative. However, host detection and infection by EPN IJs is likely to be very different to that of insect parasitoids, which forage over long distances and parasitise multiple hosts. In this study, the efficacy of nematodes at a site is independent of pine weevil density at that site and moreover, the percentage parasitism in a stump is generally independent of num-

\section{Acknowledgments}

We thank Ms. Aileen Foster for assistance with the fieldwork and Dr. Christopher Harvey for helpful discussions. The work was financially supported by the European Regional Development Fund (INTERREG IVA) administered through the Welsh European Funding Office (IMPACT project), and by the Irish National Development Plan through COFORD, the National Council for Forest Research and Development (ABATE project).

Appendix A. Site locations (latitude and longitude), altitude and number of replicates of previously unpublished data reported in the present paper

\begin{tabular}{|c|c|c|c|c|c|c|}
\hline \multirow[t]{2}{*}{ Site name } & \multirow[t]{2}{*}{ Year of application } & \multirow[t]{2}{*}{ Latitude } & \multirow[t]{2}{*}{ Longitude } & \multirow[t]{2}{*}{ Altitude $(M>0 . d)$} & \multicolumn{2}{|c|}{ Number of replicates } \\
\hline & & & & & Emergence & Parasitism \\
\hline Glendine & 2007 & $53^{\circ} 3^{\prime}$ & $-7^{\circ} 38^{\prime}$ & 380 & 19 & 10 \\
\hline Summerhill & 2010 & $53^{\circ} 27^{\prime}$ & $-6^{\circ} 44^{\prime}$ & 90 & 10 & 10 \\
\hline Killduff & 2011 & $53^{\circ} 20^{\prime}$ & $-7^{\circ} 19^{\prime}$ & 93 & $\mathrm{n} / \mathrm{a}$ & 10 \\
\hline Ballymacshaneboy & 2007 & $53^{\circ} 20^{\prime}$ & $-8^{\circ} 35^{\prime}$ & 212 & $13-14$ & 10 \\
\hline Lackenrea trial 1 & 2007 & $52^{\circ} 10^{\prime}$ & $-7^{\circ} 48^{\prime}$ & 170 & $14-16$ & 10 \\
\hline Lackenrea trial 2 & 2007 & $52^{\circ} 09^{\prime}$ & $-7^{\circ} 48^{\prime}$ & 175 & $13-15$ & 20 \\
\hline Deerpark & 2007 & $52^{\circ} 08^{\prime}$ & $-6^{\circ} 44^{\prime}$ & 260 & 21 & 20 \\
\hline The Rodneys & 2007 & $52^{\circ} 15^{\prime}$ & $-8^{\circ} 56^{\prime}$ & 230 & 18 & $\mathrm{n} / \mathrm{a}$ \\
\hline Knockeen & 2007 & $52^{\circ} 12^{\prime}$ & $-7^{\circ} 10^{\prime}$ & 50 & 15 & $\mathrm{n} / \mathrm{a}$ \\
\hline Mount Leinster & 2008 & $52^{\circ} 38^{\prime}$ & $-6^{\circ} 47^{\prime}$ & 385 & 20 & $\mathrm{n} / \mathrm{a}$ \\
\hline Drumcor & 2008 & $54^{\circ} 6^{\prime}$ & $-9^{\circ} 12^{\prime}$ & 100 & 10 & $\mathrm{n} / \mathrm{a}$ \\
\hline Glennakeel & 2008 & $52^{\circ} 15^{\prime}$ & $-7^{\circ} 21^{\prime}$ & 270 & 20 & $\mathrm{n} / \mathrm{a}$ \\
\hline
\end{tabular}

ber of weevils in that stump. There was a negative association between the density of two species of sciarid hosts on Steinernema feltiae (Filipjev) efficacy (Grewal et al., 1993; Grewal and Richardson, 1993) and between Otiorhynchus ligustici (L.) density and the efficacy of $H$. bacteriophora (Shields et al., 1999). Efficacy of Steinernema scapterisci Nguyen and Smart, when controlling mole crickets (Scaptriscus spp.) on golf courses, was positively associated with host density (Parkman et al., 1994). Most studies of EPN efficacy, however, either do not explicitly test for density dependence or else they report inconsistent trends.

When considering host density effects in EPN it is necessary to distinguish between density dependence in efficacy and density dependence in persistence, the latter of which involves recycling in hosts and so might be more likely. Harvey (2010) noted an effect of weevil density on $S$. carpocapsae populations in the soil around and in the bark of stumps one year after application and suggested that higher weevil density promoted persistence via recycling.

A number of pine weevil management recommendations may be made as a result of the present meta-analysis. Ideally, H. downesi would be exploited instead of $S$. carpocapsae, but this is dependent on successful mass production of the species at an economically viable price. Our results also suggest that EPN control of pine weevil may be more effective on forestry sites where the soil type is peat. Since weevil numbers are lower in spruce than in pine (von Sydow and Birgersson, 1997; Dillon and Griffin, 2008, Fig. 1 of present study) and efficacy is independent of host density in this system, it is likely that EPN will be most successful at reducing weevil populations below economic thresholds on sites with spruce stumps. Focusing EPN efforts on large, accessible peaty sites, on which spruce or other tree species less-favoured by weevils were felled, as part of a landscape-level control strategy may help to reduce the meta-population of weevils in an environmentally safe manner.

\section{References}

Alumai, A., Grewal, P.S., Hoy, C.W., Willoughby, D.A., 2006. Factors affecting the natural occurrence of entomopathogenic nematodes in turfgrass. Biol. Control $36,368-374$

Boemare, N., Laumond, C., Mauleon, H., 1996. The entomopathogenic nematodebacterium complex: biology, life cycle and vertebrate safety. Biocontrol Sci. Technol. 6, 333-346.

Brixey, J.M., Moore, R., Milner, A.D.J., 2006. Effect of entomopathogenic nematode (Steinernema carpocapsae Weiser) application technique on the efficacy and distribution of infection of the large pine weevil (Hylobius abietis L.) in stumps of Sitka spruce (Picea sitchensis Carr.) created at different times. For. Ecol. Manage. 226, 161-172.

Butterfield, J., 1999. Changes in decomposition rates and Collembola densities during the forest cycle in conifer plantations. J. Appl. Ecol. 36, 92-100.

Campbell, J.F., Lewis, E., Yoder, F., Gaugler, R., 1996. Entomopathogenic nematodes (Heterorhabditidae and Steinernematidae) spatial distribution in turfgrass. Parasitology 113, 473-482.

Choo, H.Y., Kaya, H.K., 1991. Influence of soil texture and presence of roots on host finding by Heterorhabditis bacteriophora. J. Invertebr. Pathol. 58, 279-280.

Coillte, 2012. Draft district strategic plans (2011-2015). Available from: <http:// www.coillte.ie/coillteforest/plans/district_strategic_plans/ district_strategic_plans_2011_2015/>.

Dillon, A.B., Ward, D., Downes, M.J., Griffin, C.T., 2006. Suppression of the large pine weevil Hylobius abietis (L.) (Coleoptera: Curculionidae) in pine stumps by entomopathogenic nematodes with different foraging strategies. Biol. Control 38, 217-226.

Dillon, A.B., Downes, M.J., Ward, D., Griffin, C.T., 2007. Optimizing application of entomopathogenic nematodes to manage large pine weevil, Hylobius abietis L. (Coleoptera: Curculionidae) populations developing in pine stumps, Pinus sylvestris. Biol. Control 40, 253-263.

Dillon, A.B., Moore, C.P., Downes, M.J., Griffin, C.T., 2008. Evict or infect? Managing populations of the large pine weevil, Hylobius abietis, using a bottom-up and top-down approach. For. Ecol. Manage. 255, 2634-2642.

Dillon, A., Griffin, C., 2008. Controlling the large pine weevil, Hylobius abietis, using natural enemies. Silviculture/Management No. 15. Coford Connects, Dublin.

Dillon, A.B., Foster, A., Williams, C.D., Griffin, C.T., 2012. Environmental safety of entomopathogenic nematodes - effects on abundance, diversity and community structure of non-target beetles in a forest ecosystem. Biol. Control 63, 107-114.

E.C., 2012. Proposal for a revised directive of the European Parliament and of the Council on Priority Substances in the field of water quality. MEMO 12/59.

Ehlers, R.-U., Hokkanen, H.M.T., 1996. Insect biocontrol with non-endemic entomopathogenic nematodes (Steinernema and Heterorhabditis spp.): 
conclusions and recommendations of a combined OECD and COST Workshop on Scientific and Regulatory Policy Issues. Biocontrol Sci. Technol. 6, 295-302.

Ennis, D., 2009. Behavioural interactions between the large pine weevil, Hylobius abietis L. (Coleoptera: Curculionidae), and entomopathogenic nematodes. Ph.D. Thesis, National University of Ireland Maynooth.

Ennis, D.E., Dillon, A.B., Griffin, C.T., 2010. Simulated roots and host feeding enhance infection of subterranean insects by the entomopathogenic nematode Steinernema carpocapsae. J. Invertebr. Pathol. 103, 140-143.

Evans, H., Moore, R., Heritage, S., Wainhouse, D., 2004. Developments in the integrated management of pine weevil, a pest of restocking in conife plantations. In: Forest Research Annual Reports and Accounts 2003-2004. Edinburgh, UK.

Foth, H.D., 1978. Fundamentals of Soil Science, 6th ed. Wiley, New York.

FSC, 2011. FSC Pesticides Policy Guidance Addendum: List of Approved Derogations for use of "Highly Hazardous" Pesticides FSC-GUI-30-001a V1-0 EN, FSC, Bonn.

Georgis, R., Gaugler, R., 1991. Predictability in biological control using entomoathogenic nematodes. J. Econ. Entomol. 84, 713-720.

Georgis, R., Poinar, G.O., 1983. Effect of soil texture on the distribution and infectivity of Neoaplectana carpocapsae (Nematoda: Steinernematidae). J. Nematol. 15, 329-332.

Grant, J.A., Villani, M.G., 2003. Soil moisture effects on entomopathogenic nematodes. J. Nematol. 15, 329-332.

Grewal, P.S., Richardson, P.N., 1993. Effects of application rates of Steinernema feltiae (Nematoda: Steinernematidae) on biological control of the mushroom fly Lycoriella auripila (Diptera: Sciaridae). Biocontrol Sci. Technol. 3, 29-40.

Grewal, P.S., Tomalak, M., Keil, C.B.O., Gaugler, R., 1993. Evaluation of a genetically selected strain of Steinernema feltiae (Nematoda: Steinernematidae) on biological control of the mushroom fly Lycoriella auripila (Diptera: Sciaridae). Ann. Appl. Biol. 123, 695-702.

Grewal, P.S., Lewis, E.E., Gaugler, R., Campbell, J.F., 1994. Host finding behaviour as a predictor of foraging strategy in entomopathogenic nematodes. Parasitology $108,207-215$

Griffin, C.T., Moore, J.F., Downes, M.J., 1991. Occurrence of insect-parasitic nematodes (Steinernematidae, Heterorhabditidae) in the Republic of Ireland. Nematologica 37, 92-100.

Griffin, C.T., Joyce, S.A., Dix, I., Burnell, A.M., Downes, M.J., 1994. Characterisation of the entomopathogenic nematodes Heterorhabditis (Nematoda: Heterorhabditidae) from Ireland and Britain by molecular and cross-breeding techniques, and the occurrence of the genus in these islands. Fundam. Appl. Nematol. 17, 245-253.

Griffin, C.T., Dix, I., Joyce, S.A., Burnell, A.M., Downes, M.J., 1999. Isolation and characterisation of Heterorhabditis spp. (Nematoda: Heterorhabditidae) from Hungary, Estonia and Denmark. Nematology 1, 321-332.

Gruner, D.S., Ram, K., Strong, D.R., 2007. Soil mediates the interaction of coexisting entomopathogenic nematodes with an insect host. J. Invertebr. Pathol. 94, 1219.

Harvey, C.D., 2010. Ecological impact of entomopathogenic nematodes used to control the large pine weevil, Hylobius abietis (Coleoptera: Curculionidae). Ph.D. Thesis, National University of Ireland Maynooth.

Heritage, S., Moore, R., 2001. The assessment of site characteristics as part of management strategy to reduce damage by Hylobius. Forestry Commission Information Note 38, HMSO, UK.

Hurlbert, S.H., 1984. Pseudoreplication and the design of ecological field experiments. Ecol. Monogr. 54, 187-211.

Hutchinson, G.E., 1957. Concluding remarks. Cold Springs Harb. Symp. Quant. Biol. 22, 415-427.

Koppenhöfer, A.M., Fuzy, E.M.J., 2006. Effect of soil type on infectivity and persistence of the entomopathogenic nematodes Steinernema scarabaei, Steinernema glaseri, Heterorhabditis zealandica, and Heterorhabditis bacteriophora. J. Invertebr. Pathol. 92, 11-22.

Koppenhöfer, A.M., Kaya, H.K., Taormino, S.P., 1995. Infectivity of entomopathogenic nematodes (Rhabditida: Steinernematidae) at different soil depths and moistures. J. Invertebr. Pathol. 65, 193-199.

Kruitbos, L.M., Heritage, S., Hapca, S., Wilson, M.J., 2010. The influence of habitat quality on the foraging strategies of the entomopathogenic nematodes Steinernema carpocapsae and Heterorhabditis megidis. Parasitology 137, 303309.

Kung, S.-P., Gaugler, R., Kaya, H.K., 1990a. Soil type and entomopathogenic nematode persistence. J. Invertebr. Pathol. 55, 401-406.

Kung, S.P., Gaugler, R., Kaya, H.K., 1990b. Influence of Soil pH and Oxygen on Persistence of Steinernema spp. J. Nematol. 22, 440-445.

Kung, S.-P., Gaulgler, R., 1991. Effects of soil temperature, soil moisture, and relative humidity on entomopathogenic nematode persistence. J. Invertebr. Pathol. 57, 242-249.

Långström, B., Day, A.R., 2004. Damage, control and management of weevil pests, especially Hylobius abietis. In: Lieutier, F., Day, K.D., Grégoire, J.-C., Battisti, A.
Evans, H.F. (Eds.), Bark and Wood Boring Insects in Living Trees in Europe, a Synthesis. Springer, Dordrecht, pp. 415-444.

Leather, S.R., Day, K.R., Salisbury, A.N.J., 1999. The biology and ecology of the large pine weevil, Hylobius abietis (Coleoptera: Curculionidae): a problem of dispersal? Bull. Entomol. Res. 89, 3-16.

Lewis, E.E., Gaugler, R., Harrison, R., 1992. Entomopathogenic nematode hos finding: response to host contact cues by cruise and ambush foragers. Parasitology 105, 309-315.

Lewis, E.E., Campbell, J., Griffin, C., Kaya, H., Peters, A., 2006. Behavioral ecology of entomopathogenic nematodes. Biol. Control 38, 66-79.

Molyneux, A.S., Bedding, R.A., 1984. Influence of soil texture and moisture on the infectivity of Heterorhabditis sp. D1 and Steinernema glaseri for larvae of the sheep blowfly, Lucilia Cuprina. Nematologica 30, 358-365.

Örlander, G.R., Nilsson, U., 1999. Effect of reforestation methods on pine weevil (Hylobius abietis) damage and seedling survival. Scand. J. For. Res. 14, 341-354.

Örlander, G.R. Nordlander, G.R., 2003. Effects of field vegetation control on pine weevil (Hylobius abietis) damage to newly planted Norway spruce seedlings". Ann. Forest. Sci. 60, 667-671.

Oetting, R.D., Latimer, J.G., 1991. An entomogenous nematodes Steinernema carpocapsae is compatible with potting media environments created by horticultural practices. J. Entomol. Sci. 26, 390-394.

Owen, J.A., 1989. An emergence trap for insects breeding in dead wood. Br. J. Entomol. Nat. Hist. 2, 65-67.

Paavilainen, E., Päivänen, J., 1995. Peatland forestry ecology and principles. Ecological Studies, vol. 111. Springer-Verlag, Berlin.

Parkman, J.P., Frank, J.H., Nguyen, K.B., Smart, G.C., 1994. Inoculative release of Steinernema scapterisci (Rhabditida: Steinernematidae) to suppress pest mole crickets (Orthoptera: Gryllotalpidae) on golf courses. Environ. Entomol. 23 1331-1337.

Pitty, A.F., 1979. Geography and Soil Properties. Methuen, London.

Portillo-Aguilar, C., Villani, M.G., Tauber, M.J., Tauber, C.A., Nyrop, J.P., 1999 Entomopathogenic nematode (Rhabditida: Heterorhabditidae and Steinernematidae) response to soil texture and bulk density. Environ. Entomol. 28, 1021-1035.

Preisser, E.L., Strong, D.R., 2004. Climate affects predator control of an herbivore outbreak. Am. Nat. 163, 754-762.

Rolston, A.N., Griffin, C.T., Downes, M.J., 2005. Distribution of entomopathogenic nematodes in an Irish sand dune system. Nematology 7, 259-266.

SPSS, 2011. SPSS for Windows, Release 19.0.0. SPSS Inc., Chicago.

Stilling, P.D., 1987. The frequency of density dependence in insect host-parasitoid systems. Ecology 68, 844-856.

Shapiro, D.I., McCoy, C.W., Fares, A., Obreza, T., Dou, H., 2000. Effects of snail type on virulence and persistence of entomopathogenic nematodes in relation to control of Diaprepes abbreviatus. Environ. Entomol. 29, 1083-1087.

Shields, E.J., Testa, A., Miller, J.M., Flanders, K.L., 1999. Field efficacy and persistence of entomopathogenic nematodes Heterorhabditis bacteriophora 'Oswego' and $H$. bacteriophora 'NC' on alfalfa snout beetle larvae (Coleoptera: Curculionidae). Environ. Entomol. 28, 128-136.

Torr, P.S., Wilson, M.J., Heritage, S., 2005. Forestry applications. In: Grewal, P.S Ehlers, R.-U., Shapiro-Ilan, D.I. (Eds.), Nematodes as Biocontrol Agents. CABI Publishing, Oxfordshire, pp. 47-64, 281-293.

Torr, P., Heritage, S., Wilson, M.J., 2007. Steinernema kraussei, an indigenous nematode found in coniferous forests: efficacy and field persistence against Hylobius abietis. Agric. For. Entomol. 9, 281-294.

von Sydow, F., 1997. Abundance of pine weevils (Hylobius abietis) and damage to conifer seedlings in relation to silvicultural practices. Scand. J. For. Res. 12, 157167.

von Sydow, F., Birgersson, G., 1997. Conifer stump condition and pine weevil (Hylobius abietis) reproduction. Can. J. For. Res. 27, 1254-1262.

Wainhouse, D., Evans, H., Moore, R., Webber, J., Thorpe, K., Stanly, J., 2001. The integrated forest management programme. Forest Research Annual Report and Accounts 2000-2001. Edinburgh, UK.

Welsch, D.J., Smart, D.L., Boyer, J.N., Minkin, P., Smith, H.C., McCandless, T.L., 1995 Forested Wetlands Functions, Benefits and the Use of Best Management Practices. USDA, Forest Service, Radnor, PA.

Weslien, J., 1998. Vad kostar snytbaggeskadorna? (How much does the pine weevi damage cost?). Kunglige Skogs-och Lantbruksakademins Tidskrift 137, 19-22.

Wilson, M.J., Ehlers, R.-U., Glazer, I., 2012. Entomopathogenic nematode foraging strategies - is Steinernema carpocapsae really an ambush forager? Nematology $14,389-394$

Willoughby, I., Evans, H., Gibbs, J., Pepper, H., Gregory, S., Dewar, J., Nisbet, T., Pratt J., McKay, H., Siddons, R., Mayle, B., Heritage, S., Ferris, R., Trout, R., 2004 Reducing pesticide use in forestry. In: Forestry Commission Practice Guide. Forestry Commission, Edinburgh. 